\title{
Risk and uncertainty
}

\author{
Sheila Dow
}

Published in R Dimand and H Hagemann (eds), The Elgar Companion to John Maynard Keynes. Cheltenham: Edward Elgar, 2019, pp. 431-41.

\begin{abstract}
Uncertainty, as unquantifiable risk, was central to Keynes's philosophy and economics, and continues to be relevant under modern conditions. For Keynes, knowledge is in general uncertain because of the organic nature of the subject matter; quantifiable risk is the special case. He developed a theory of how in practice we can still establish grounds for belief under uncertainty, drawing on weight of argument and multiple strands of reasoning, such that uncertainty is a matter of degree. The degree of uncertainty influences fundamentally the key variable in Keynes's theory of effective demand: planned investment. Further, money plays a crucial role as the refuge from uncertainty, such that the rate of interest is a monetary rate. Applied to modern institutions and conditions, this theory is shown to explain the recent crisis.
\end{abstract}

Keywords: Keynes, uncertainty, risk, investment, liquidity preference, financial crisis

\section{INTRODUCTION}

Conventionally, uncertainty is the subset of risk which is not quantifiable. The fundamental issue for economics surrounds the relative size of that subset; for Keynes it was extremely large, whereas for mainstream economics it is small, if not non-existent. In what follows we will (unless otherwise specified) use the term 'risk' to refer only to that subset of total risk which is quantifiable.

The distinction between risk and uncertainty is central to Keynes's approach to economics, and is fundamental in particular, through his theory of expectations, to his theory of investment and his theory of money and interest. The centrality of uncertainty follows on from his earlier philosophical work on probability. ${ }^{1}$ It is now conventional in Keynes studies to accept this continuity, ${ }^{2}$ but the inattention to the philosophical foundation and character of Keynes's economics was common throughout the post-war years of Keynesian policy when uncertainty was relatively absent (owing, arguably, to that policy stance). This inattention has also dogged the explanation for the economic and financial crisis which began in 2007, and the application of 'Keynesian' policies to its resolution.

The purpose of what follows is to provide an account of Keynes's thinking on risk and uncertainty, beginning with A Treatise on Probability and proceeding to discuss its development and application in The General Theory. We conclude by considering briefly the modern relevance of Keynes's thinking on uncertainty and risk.

\section{A TREATISE ON PROBABILITY, RISK AND UNCERTAINTY}

Keynes (1921 [1973]) set out in A Treatise on Probability to analyse the grounds for belief under uncertainty, as the basis for action. Rather than classical logic, which deals with 
demonstrable conclusions deduced on the basis of true premises, he set out to establish a new type of logic to account for the general case of inconclusive argument, that is, uncertainty. $\mathrm{He}$ begins as follows: 'Part of our knowledge we obtain direct; and part by argument. The Theory of Probability is concerned with that part which we obtain by argument' (Keynes 1921 [1973], p. 3).

Like Knight (1921), Keynes discussed uncertainty in terms of an absence of numerically quantifiable probability, distinguishing it from the modern understanding of risk. ${ }^{3}$ Quantifiable risk requires knowledge of probability distributions which is conclusive (certain) either a priori or on the basis of frequency distributions; the higher the calculable volatility of mathematical expectation, the higher the risk. However, Keynes (1921 [1973], p. 290) argued that the physical and social worlds are organic, limiting the scope for quantified expectation. Organicism means that the characteristics of objects are not finite, in that relations between them are open to change, and that the laws governing the whole cannot be expected to be the same as those governing the parts (see further, Carabelli 1988 pp. 212-13). ${ }^{4}$ One consequence which is sufficient to preclude measurement of probability is an inability to enumerate instances; if we do not know the range of possible outcomes, we cannot assign a numerical probability to any one outcome.

While Keynes and Knight took the same position on the distinction between risk and uncertainty in terms of cardinal probability, Keynes explored further the significance of ordinal probability, where some scope for belief might be possible, allowing for a tri-partite distinction between cardinal (quantifiable) risk, ordinal judgements about relative degrees of probability, and the inability to make any comparison of probability at all because of incommensurability between reasons (Carabelli 1995). ${ }^{5}$ Classical logic produces the single correct solution. However, where cardinal probability cannot be measured, argument is inconclusive.

The only alternative to certainty in classical logic is ignorance, and yet, if certainty in general is not possible, how then do we justify action? Although Keynes argued that uncertainty is the general case, nevertheless action is normally taken, on rational grounds (in the broad sense of the term). As he states at the start of the Treatise, 'The Theory of Probability ... treats of the different degrees in which the results so obtained are conclusive or inconclusive' (Keynes 1921 [1973], p. 3). ${ }^{6}$ Rather than uncertainty being absolute, Keynes argued that beliefs are held with confidence of some degree or another, that is, some degree of uncertainty. Only higher degrees of uncertainty lead to inaction.

In order to analyse degrees of uncertainty, Keynes (1921 [1973], ch. 6) introduced the concept of weight of argument as something independent of probability. Evidential weight is a measure of the level of relevant evidence brought to bear in supporting a belief; the greater the relative weight, the higher the level of confidence in the belief and the lower the uncertainty. ${ }^{7}$ Given the incommensurability of much evidence and the theory-ladenness of the notion of relevance, comparison of weight (just as comparisons of probability) is problematic. Further, not only may new evidence change what is regarded as relevant, but it may also reveal new realms of ignorance (see further, Runde 1990; Dow 1995 [2012]).

Keynes provided a new theory of reasoned grounds for belief which involved mechanisms to deal with the inconclusive nature of argument by using reason and evidence to build up knowledge even though it is in general, and necessarily, uncertain. Judgements need to be made about the relevance of evidence and how it is to be applied if different pieces of evidence are incommensurate, as well as about the extent and nature of ignorance. As Keynes applied these ideas to economics, he made more use of the idea of conventional judgement and 
of animal spirits as contributors to belief, conditioning ideas of relevance and attitude to uncertainty (Davis 1994; Dow 2014). However, central to his theory of probability was that it was very rare for circumstances to yield a single correct belief, and that reasoned beliefs could change.

As Keynes makes clear in the first pages of the Treatise, an assessment of probability is objective. It is subjective only in the sense that it is conditional on the particular knowledge brought to bear, in that different agents might well arrive at different non-numerical or approximate estimates of risk, a position he sustained in his subsequent work (O'Donnell 1989, ch. 7). This was in spite of Ramsey's (1926 [1931]) argument that, even if objective quantifiable probabilities were unavailable, they are always amenable to subjective numerical estimation (the basis for the subjective expected utility approach). Just as Keynes had sought to establish belief on rational grounds rather than Moore's reliance on convention as an alternative to reason, Keynes (1931 1972), p. 339) objected to Ramsey's justification of induction simply as being a 'useful mental habit'.

Keynes (1921 [1973], p. 25) referred to risks which can be insured against on the basis of probability which can be 'estimated between comparatively narrow numerical limits' and uninsurable risk. Even if, in principle, Lloyds is prepared to quote insurance for any risk, what is being estimated is not actual risk, but some reasonable upper bound to risk (Feduzi et al. 2012). As Keynes (1921 [1973], p. 176) states: 'Many probabilities, which are incapable of numerical measurement, can be placed nevertheless between numerical limits. And by taking particular non-numerical probabilities as standards a great number of comparisons or approximate measurements become possible.'

However, in general, insurance policies exclude a whole range of events whose probability cannot be calculated on the basis of stable historical frequency distributions, that is, because of uncertainty. In society more broadly, an unwillingness to arrive at subjective probabilities in order to decide how to act is the defining characteristic of a situation of high uncertainty. The subjective expected utility approach which builds on Ramsey's position does not allow for an unwillingness to place bets (Runde 1995).

\section{THE GENERAL THEORY, RISK AND UNCERTAINTY}

Keynes's philosophy provided the foundation for The General Theory. The generality of uncertainty required an approach which involved a plurality of methods and lines of argument in order to increase weight. This approach contrasted with the orthodoxy of then, as now, which required the building up of a formal mathematical system presumed to yield conclusive arguments. Keynes's approach was evident in the structure of argument of The General Theory, in his explicit arguments against mathematical formalism (see further, O'Donnell 1989, ch. 9), and in the way in which he expressed his critique of the prevailing orthodoxy in terms of the unwarranted assumption of demonstrative argument based on calculable probability. As Keynes (1937 [1973], p. 112) put it, in his subsequent encapsulation of The General Theory:

<quotation>[T] hese more recent writers like their predecessors were still dealing with a system in which the amount of the factors employed was given and the other relevant facts were known more or less for certain. ... [A]t any given time facts and expectations were assumed to be given in a definite and calculable form; and risks, of which, though admitted, not much notice was taken, were supposed to be capable of an exact actuarial computation. The calculus of 
probability, though mention of it was kept in the background, was supposed to be capable of reducing uncertainty to the same calculable status as that of certainty itself ...</quotation>

Keynes's organicism was evident in the content of his economic theory, notably in his focus on the fallacy of composition, as in the paradox of saving. ${ }^{8}$ More specifically, the distinction between risk and uncertainty, which is the consequence of organicism, had particular consequences for Keynes's theory of investment and his theory of money and interest, both of which lay at the core of his theory of effective demand (Carabelli 1988, chs 11, 12; Runde 2003). In line with the Treatise on Probability, Keynes (1936 [1973], p. 148, 1937 [1973], p. 113) emphasised the distinction between expectations and the confidence held in them. ${ }^{9}$

Keynes drew a particular distinction between the expectations of the entrepreneur and of the stock market when it came to the investment decision, and to the expectations in the bond and money markets in determining the rate of interest. Differences in the degree of uncertainty between and within different groups of decision-makers, and over time, are the result of the different knowledge being brought to bear, including the different conventional judgements embedded in that knowledge, that is, they result from different arguments and weights of argument.

Uncertainty is highest in general in respect of long-term expectation, which is the relevant term for physical investment decisions (see further, Meeks 1976 [2003]). Since the basis in reason and evidence for such expectations is inevitably weak, entrepreneurs rely on conventional judgements of peers and of experts, and assume the present to be a better guide than reason would actually support (Keynes 1937 [1973], p. 114). Were the present and past to be a reliable guide to the future, risk would be quantifiable, so the convention involves ignoring uncertainty, up to a point. Entrepreneurs as a group have a particular facility for doing so, giving rein to animal spirits as a basis for action. Further, where entrepreneurs are dependent on external finance, they are dependent on the expectations of providers of finance as regards the return on investment. In attempting to make their arguments in favour of investment projects more conclusive, long-term expectations are conventionally encapsulated in an expectation as to the marginal efficiency of capital for comparison with the cost of finance (Keynes 1936 [1973], ch. 11). In this way, entrepreneurs 'save' their 'faces as rational men' (Keynes 1937 [1973], p. 114).

Yet Keynes (1936 [1973], p. 159) proceeded to spell out the uncertainty surrounding any such long-term expectations, and the problems caused by the short-term orientation of providers of finance. Some of the knowledge drawn on by entrepreneurs is also drawn on by markets in valuing firms' assets. However, different forms of knowledge will be relevant to different time frames, altering the weight attached to valuations by each party. Second, uncertainty is less, other things being equal, the shorter the time horizon, therefore judgements as to probabilities can be more assured. ${ }^{10}$ However, a further consequence is that a short time horizon picks up changes in conventional valuations with the emergence of 'news', which may be irrelevant to the long-term outcome. Keynes argued that pursuit of short-term gain from placing bets on changing market valuations may create more volatility ('bubbles on a steady stream of enterprise', ibid.). Some beliefs are more reasonable than others, but none can be conclusive. A core conclusion therefore was that a 'true' valuation of assets was not possible. ${ }^{11}$

Keynes attributed the short-term orientation of stock market valuation to the 'fetish of liquidity' (Keynes 1936 [1973], p. 155). His theory of money and interest was built on the concept of uncertainty. The 'necessary condition [for the existence of liquidity preference for money as a means of holding wealth] is the existence of uncertainty as to the future rate of 
interest' (Keynes 1936 [1973], p. 168, original emphasis). Were all risk quantifiable, the demand for an asset which earned no return (other than liquidity) would be immaterial (Keynes 1937 [1973], p. 115; Chick 1983, p. 214).

The rate of interest is thus not determined in the market for loanable funds but in the money market, and is the outcome of the degree of confidence in expectations. It is the confidently held belief among most investors that interest rates can only rise that accounts for the liquidity trap (Keynes 1936 [1973], p. 207). Even when expectations are held with confidence, they are inevitably based on beliefs which can shift discretely and which can differ, as between groups of investors. Thus the speculative demand for money, and shifts in it, can influence the rate of interest and thus real expenditure plans. However, the precautionary demand for money can also influence interest rates, rising when uncertainty becomes more marked. ${ }^{12}$ Money at a more fundamental level is a societal response to uncertainty, providing some protection against it: 'our desire to hold money as a store of wealth is a barometer of our distrust of our own calculations and conventions concerning the future ... The possession of actual money lulls our disquietude' (Keynes 1937 [1973], p. 116).

\section{THE CONTINUING RELEVANCE OF KEYNES ON RISK AND UNCERTAINTY}

For all the changes in socio-economic structures and practices since Keynes's day, his approach to uncertainty still holds good. Developments in the financial sector and in economic theory since his time have further cemented the mainstream stance on calculable probability against which Keynes was arguing. The institutional response to rising financial volatility from the 1970s was to develop investment strategies and financial regulation based on models which presume risk to be quantifiable. The confidence that risk was thus being successfully managed meant that great weight was attached to the default risk valuations of lenders and expectations as to asset price movements. However, since, according to Keynes's theory, these valuations were inconclusive beliefs, they were vulnerable to discrete shifts in the face of new information about risk. ${ }^{13}$ New evidence revealed unnoticed realms of ignorance, dramatically reducing evidential weight and thus increasing uncertainty. The outcome was an increase in liquidity preference across the board and thus an unwillingness to make expenditure plans or to finance them (Bibow 2009).

This brief account is an indication that Keynes's theory of uncertainty is a good explanation for the recent crisis, providing a strong foundation for a policy response which takes uncertainty seriously (Skidelsky 2011). Similarly, the experience of the crisis illustrates the real economic problems which can arise if the Keynesian distinction between risk and uncertainty is not addressed, in theory or in practice.

\section{NOTES}

1. Keynes began working on probability in 1906.

2. This development followed on from the pioneering work by Carabelli (1988) and O'Donnell (1989) on Keynes's (1921 [1973]) Treatise on Probability. 
3. In the Treatise, Keynes made only limited use of the term 'risk', in its general sense, including unquantifiable risk. Keynes (1921 [1973], pp. 344-8) focused on moral risk, referring to moral judgement in respect of the risk that a desired outcome not be achieved. (This was contrasted with 'physical risk' which corresponded to quantifiable risk.) Keynes argued that the desirability of an action may not vary in a linear fashion with the probability if producing the desired result and not achieving it, even if that probability could be quantified.

4. In modern parlance, the subject matter is an open system; see Chick and Dow (2005 [2012]).

5. Keynes (1921 [1973], p. 32) illustrated this point with an issue of practical reason: how to decide on whether or not to take an umbrella when the 'barometer is high but the sky is black' (reflecting two incommensurate pieces of reasoning).

6. In allowing for uncertainty to vary by degree, Keynes differed from Knight's binary focus on uncertainty versus risk.

7. Keynes also considered a more complex notion: relevant knowledge relative to relevant ignorance. The complexity of this notion stems from the theory-ladenness of the notion of relevance, and the possibility that more evidence reveals more ignorance (see further, Dow 1995 [2012]).

8. The paradox arises when the intentions at the individual level to increase saving are confounded by the dampening effect on aggregate demand, and thus on incomes.

9. In a letter to Townshend, Keynes (1938 [1979]) made this distinction explicit in the distinction between the risk premium and the liquidity premium, respectively.

10. It is telling that Keynes (1936 [1973], p. 159) likened the stock market to a casino, which is one of the few contexts in which quantifiable probability (more or less) applies.

11. This argument was elaborated on by Townshend (1937).

12. See Runde (1994) for a derivation of Keynes's theory of liquidity preference from $A$ Treatise on Probability.

13. In the case of the crisis which emerged in 2007, the new information was evidence of default on subprime mortgages.

\section{REFERENCES}

Bibow, J. (2009), Keynes on Monetary Policy, Finance and Uncertainty: Liquidity Preference Theory and the Global Financial Crisis, London: Routledge.

Carabelli, A. (1988), On Keynes's Method, London: Macmillan.

Carabelli, A. (1995), 'Uncertainty and measurement in Keynes: probability and organicness', in S. Dow and J. Hillard (eds), Keynes, Knowledge and Uncertainty, Aldershot, UK and Brookfield, VT, USA: Edward Elgar, pp. 137-60. 
Chick, V. (1983), Macroeconomics After Keynes, Oxford: Philip Allan.

Chick, V. and Dow, S. (2005), 'The meaning of open systems', Journal of Economic Methodology, 12 (3), 363-81, repr. 2012 in S. Dow, Foundations of New Economic Thinking, London: Macmillan, pp. 178-96.

Davis, J.B. (1994), Keynes's Philosophical Development, Cambridge: Cambridge University Press.

Dow, S. (1995), 'Uncertainty about uncertainty', in S. Dow and J. Hillard (eds), Keynes, Knowledge and Uncertainty, Aldershot, UK and Brookfield, VT, USA: Edward Elgar, pp. 11727, repr. 2012 in S. Dow, Foundations of New Economic Thinking, London: Macmillan, pp. 72 82 .

Dow, S. (2014), ‘Animal spirits and organization', Journal of Post Keynesian Economics, 37 (2), 211-32.

Feduzi, A., J. Runde and C. Zappia (2012), 'De Finetti on the insurance of risks and uncertainties', British Journal of the Philosophy of Science, 63 (2), 329-56.

Keynes, J M (1921), A Treatise on Probability, repr. 1973 in D. Moggridge (ed.), The Collected Writings of John Maynard Keynes, vol. VIII. London: Macmillan, for the Royal Economic Society.

Keynes, J.M. (1931), 'Frank Ramsey', in Essays in Biography, Collected Writings, repr. 1972 in D. Moggridge (ed.), The Collected Writings of John Maynard Keynes, vol. X, London: Macmillan, for the Royal Economic Society, pp. 335-6.

Keynes, J.M. (1936), The General Theory of Employment, Interest and Money, repr. 1973 in D. Moggridge (ed.), The Collected Writings of John Maynard Keynes, vol. VII. London: Macmillan, for the Royal Economic Society.

Keynes, J.M. (1937), 'The General Theory of Employment', Quarterly Journal of Economics, 51, 209-23, repr.1973 in The General Theory and After, Part II: Defence and Development, in D. Moggridge (ed.), The Collected Writings of John Maynard Keynes, vol. XIV, London: Macmillan for the Royal Economic Society, pp. 109-23.

Keynes, J.M. (1938), 'Letter to Hugh Townshend, 7 December', repr. 1979 in The General Theory and After: A Supplement, in D. Moggridge (ed.), The Collected Writings of John Maynard Keynes, vol. XXIX, London: Macmillan for the Royal Economic Society, pp. 293-4.

Knight, F.H. (1921), Risk, Uncertainty and Profit, Chicago, IL: University of Chicago Press.

Meeks, G. (1976), 'Keynes on the rationality of decision procedures under uncertainty: the investment decision', mimeo, University of Cambridge, repr. 2003 in J. Runde and S. Mizuhara (eds), The Philosophy of Keynes's Economics, London: Routledge, pp. 19-36.

O'Donnell, R.M. (1989), Keynes's Philosophy, Economics and Politics: the Philosophical Foundations of Keynes's Thought and Their Influence on His Economics and Politics, London: Macmillan. 
Ramsey, F.P. (1926), 'Truth and probability', repr. 1931 in R.B. Braithwaite (ed.), The Foundations of Mathematics and Other Logical Essays, London: Routledge and Kegan Paul, ch. 7.

Runde, J. (1990), 'Keynesian uncertainty and the weight of arguments', Economics and Philosophy, 6 (2), 275-92.

Runde, J. (1994), 'Keynesian uncertainty and liquidity preference', Cambridge Journal of Economics, 18 (2), 129-44.

Runde, J. (1995), 'Risk, uncertainty and Bayesian decision theory: a Keynesian view', in S. Dow and J. Hillard (eds), Keynes, Knowledge and Uncertainty, Aldershot, UK and Brookfield, VT, USA: Edward Elgar, pp. 197-210.

Runde, J. (2003), 'On some explicit links between Keynes's, A Treatise on Probability and The General Theory', in J. Runde and S. Mizuhara (eds), The Philosophy of Keynes's Economics, London: Routledge, pp. 46-54.

Skidelsky, R. (2011), 'The relevance of Keynes', Cambridge Journal of Economics, 35 (1), 113.

Townshend, H. (1937), 'Liquidity-premium and the theory of value', Economic Journal, 47 (March), 157-69. 